\title{
The Effects Of Water Utility Pricing On Low Income Consumers
}

\author{
Donald A. Forrer, D.B.A., Hodges University, USA \\ Jacob Boudreau, Hodges University, USA \\ Elizabeth Boudreau, Hodges University, USA \\ Sheronia Garcia, Hodges University, USA \\ Christopher Nugent, Hodges University, USA \\ Dean Allen, Hodges University, USA \\ Alexis C. Lubin, Hodges University, USA
}

\begin{abstract}
This study reviews ten water utilities in Florida utilizing current pricing models to determine how municipal utilities approach affordability. Water is no longer a commodity that can be taken for granted as the effects on the family budget has risen considerably in the past couple of decades. Increasing costs in capital, debt, personnel, chemicals, retrieval, and production have dramatically increased the price of water. Municipalities are faced with diminishing resources, escalating costs, and the need to consider those less fortunate when determining utility pricing. This research reviews programs available to utilities to offset the effect on capital requirements if municipalities adapt a low income friendly pricing model. Ten Florida municipalities are examined utilizing data from the 2012 Water and Wastewater Rate Study conducted for the American Water Works Association. Additionally, affordability programs for all ten municipalities are reviewed.
\end{abstract}

Keywords: Utilities; Affordability; Rate Model; Municipality; Low Income; Water

\section{INTRODUCTION}

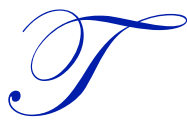

his research serves as a review of relevant literature and design of a methodology for a study to be conducted over the next several months. This study reviews ten water utilities in Florida utilizing current pricing models to determine how municipal utilities approach affordability. The municipalities include: 1) Okaloosa County Water \& Sewer, 2) Gainesville Regional Utilities, 3) JEA (Jacksonville), 4) Lakeland City Water Utilities, 5) Melbourne City Water, 6) Miami-Dade Water \& Sewer, 7) Orange County Utilities, 8) Broward County Water \& Sewer, 9) St. Petersburg Water, and 10) City of Cocoa. The purpose of the study is to develop a methodology for municipal utilities to aid those who cannot afford an ever increasing cost of water and wastewater service.

There was a time when water was a commodity that families took for granted and cost was not a consideration in the budget. However, that is no longer the case. Increasing costs in capital, debt, personnel, chemicals, retrieval, and production have dramatically increased the price of water. In addition to the listed issues is the fact that water is becoming harder to find and maintain as municipalities face revenue issues that must be addressed through the pricing model utilized by government utilities. Low income consumers are usually treated like all citizens by most pricing models. This is an issue that municipalities must address in the near future.

Public utilities are required to be self-sufficient by ensuring that income covers expenses. Municipalities are limited in their ability to ensure low income citizens are not priced out of the vital utilities required for survival. Many rely on government programs designed for housing or other welfare programs. As costs continue to increase, municipalities are adjusting policies to consider low income members of society. Two principles are utilized to determine rates for utilities.

\footnotetext{
${ }^{1}$ All rights reserved. No part of this research may be used or reproduced by any means, graphic, electronic, or mechanical, including photocopying, recording, taping or by any information storage retrieval system without the written permission of the author except in the case of brief quotations embodied in critical articles and reviews.
} 
The benefits principle dictates that all users pay equally according to the benefit they receive. The ability to pay principle is based on an ability to pay. Until recently, the benefits principle usually applied in pricing models used by most municipalities. This research will examine if municipalities should consider a pro-poor methodology in addition to other popular models.

Additionally, this research attempts to identify alternatives to meet capital demands and support low income members of the community. This paper is the first in a series that will address pricing models and alternatives by the review of ten large systems in Florida. This paper will represent an introduction to the problem and is conducted by a team of researchers from Hodges University.

\section{AFFORDABILITY (STATE AND NATIONAL)}

There are many considerations in a typical rate model. Figure 1 illustrates how traditional pricing models are effected by the need to address those who cannot pay.

Figure 1. Conceptual Pricing Model. Developed by Authors

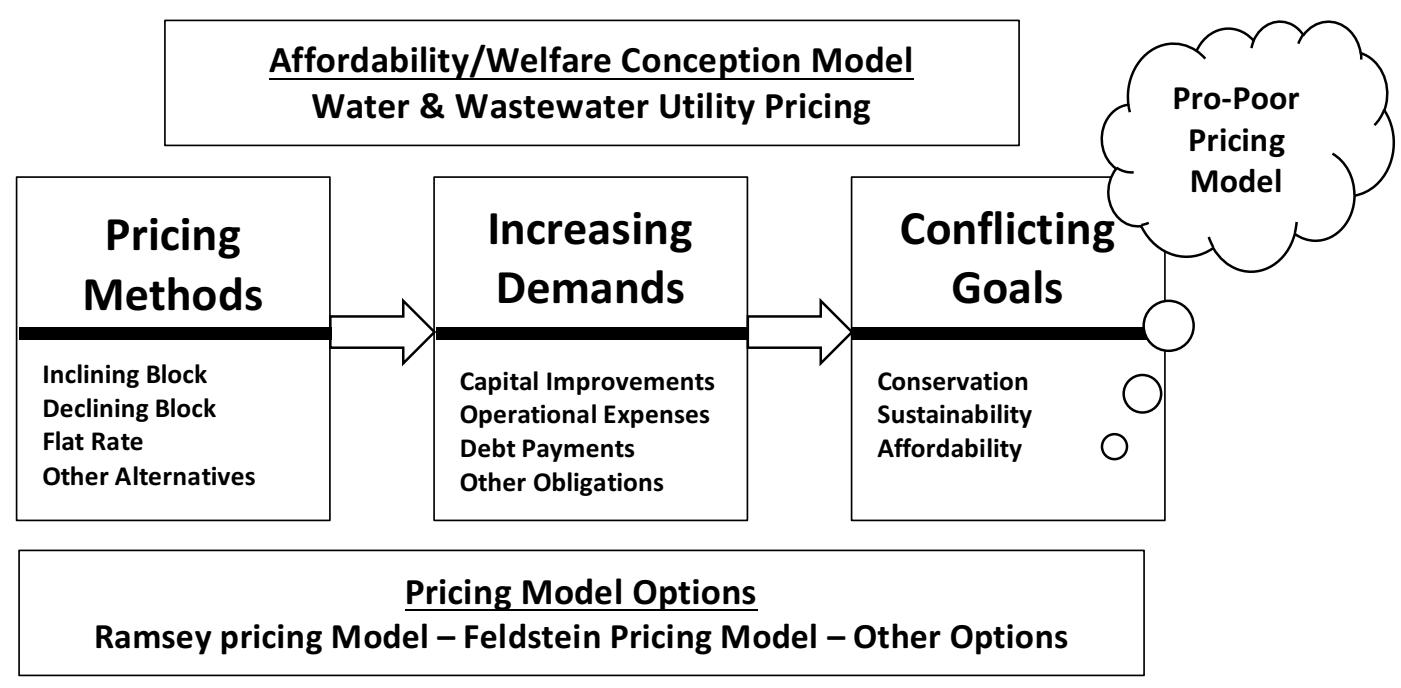

Figure 1 examines elements of a utility rate model that are used to create an economic and equity balance for governmental agencies for funding critical water and wastewater resources. Municipalities are faced with diminishing resources, escalating costs, and the need to consider those less fortunate when determining utility pricing. This research examines the effect on capital requirements if municipalities consider a low income friendly pricing model. The ten Florida municipalities are examined by reviewing data from the 2012 Water and Wastewater Rate Study conducted for the American Water Works Association and information gathered by the authors. Data elements include: population served, average income, poverty level index, employees, accounts, usage, income, capital expenditures, capacity, production, price structure, rates, and a host of other data. Additionally, affordability programs for all ten municipalities are reviewed. This was accomplished by interviewing and visiting government officials and through available literature.

Affordability issues are complicated in typical rate models by the fact that diminishing resources and escalating costs create fiscal issues when considering those less fortunate while creating a utility pricing model. Research indicates that a pro-poor pricing model that considers the affordability index economic model to determine cost to consumers could be successful if supported by funding. The Affordability Index (AI) is measured by average household water charges (WB) divided by average household income (Y).

$$
\mathrm{AI}=\mathrm{WB} / \mathrm{Y}
$$


Affordability programs for all ten municipalities are examined in this initial study to determine organizational needs for a pro-poor pricing model. Nordin (1976), explained how consumer income is included in the demand function. Nordin's (1976) model is listed below:

$$
Q=\beta_{0}+\beta_{1} P+\beta_{2} M P+\beta_{3} D+\beta_{4} Y
$$

Where:

$$
\begin{aligned}
& Q=\text { units of water purchased } \\
& P=\text { a price vector for other relevant goods } \\
& M P=\text { marginal price of water in the block consumption } \\
& D=\text { Lump-sum income effect } \\
& Y=\text { consumer income }
\end{aligned}
$$

In this model, the difference between the marginal price and the consumer price involves a tariff for the community. This action is necessary to reduce costs on those who cannot afford to pay, but could violate regulations concerning utility pricing models and state and federal self-sufficiency requirements. The inclining block rate is a pricing model that encourages reduced usage, but directly effects low income users with large families.

\section{AFFORDABILITY (STATE AND NATIONAL)}

This section discusses available programs for those in need. Affordability on the national, state and local level are created to assist individuals and relieve a financial burden by constructing programs that allow those in need to pay various obligations at a lower rate due to economic situation. Even though the affordability programs seem to be a worthy tool, the programs have numerous pitfalls due to the difficulty for staff to determine who qualifies and fragmented eligibility requirements. Affordability utilities programs were designed to provide assistance to individuals and families not exceeding a specific yearly income and normally do not consider the debt level in the household.

For the most part, the State of Florida relies on individual municipalities and organizations to create their own incentives for affordability. However, there are examples of stated funded programs. Examples of affordability programs in the state include the foundation for Low-Income Rate Assistance programs (LIRA) created by Key West City Electric, Tallahassee Utilities and Tampa Electric. LIRA provides long term monetary assistance for utilities to individuals and families who qualify. However, qualifying factors vary for every organization. In an effort to aid with affordability, Florida passed the "William E Sadowski Affordable Housing Act" in 1991. This act incorporated programs such as the Florida Weatherization Assistance Program (WAP) and State Housing Initiative Partnerships (HAP) in an effort to consolidate help for those in need.

The Weatherization Assistance Program (WAP) provides grants to the community action agencies, local governmental agencies, non-profit agencies and Native American tribes. This program allows grants not exceeding $\$ 2,600$ per residences, to install or repair items such as HVAC systems, water heater wraps and insulation (Florida Weatherization, n.d.). These items are only a few example of the many services offered by WAP. The eligibility for this program has two requirements; 1) the individual must be a Florida citizen and, 2) the household family income for a family of three, before taxes, must be equal to or less than $\$ 40,108$ (Eligibility requirements, 2015).

Additionally, not all communities maintain affordability assistance program for citizens who warrant assistance. Many rely on services available through community organizations such as Care to Share (CTS) founded by Florida Power and Light and Low Income Home Energy Assistance Program (LIHEAP). These services are designed for individuals who specifically need assistance with electricity and water costs. Local religious organizations are relied on heavily by the low income community.

Florida Low-Income Home Energy Assistance Program (LIHEAP) is a utility program that is designed to help impoverished families pay for the cost of their utility bills. LIHEAP also provides assistances during crises and weather related issues. As an example, a family of three must have a household income equal to or less than 
$\$ 30,135.00$ to be eligible for this program (LIHEAP, n.d.). Individuals who participate, or have a family member participating in SNAP, Supplemental Security (SSI), Temporary Assistance for Needy Families (TANF) or "certain need's tested Veterans benefits" are automatically eligible to apply for this assistance. TANF is designed to provide assistance to low income families by ending the parental dependence on governmental aid. This program promotes job training and job preparation. The requirements for eligibility include being a Florida resident, either pregnant or currently responsible for a child under the age of 19 years old who is a US Citizen, have low to very low income, working for minimal wages (under-employed), unemployed or soon to be unemployed (Benefits in Florida, n.d.).

Affordability programs are provided for those who do not have the ability to financially afford the cost of living according to the federal government. Without looking into additional factors of what the household income can or cannot afford the government is unable to accurately identify all of the factors effecting poverty. In many cases, affordability programs are designed to allow individuals to apply for the aide once every 12 months. Once the 12month period is completed an individual is permitted take part in the re-application process (LIHEAP, n.d). LIHEAP allows for individuals to apply for benefits once every twelve months. The benefits received vary in terms of regular home energy assistance. For instance, a household can receive $\$ 150$ - $\$ 300$ dependent on the household size and income. LIHEAP is not designed to fund an individual's entire utility bill, but to work as an aide in elevating the financial burden to low-income families. Other agencies have benefits to help families in other areas such as purchasing or renting homes, pre-paid cellular phones, healthcare, supplemental nutrition and many more.

Each county in the state of Florida is able and encouraged to adopt personal low-income affordability assistance programs. Florida Power and Light (FPL) offers affordability plans in addition to Care to Share (CTS). As mentioned earlier, CTS is an organization founded by FPL and funded by donations. Funds are then distributed to low-income families to help manage utility payments. In 2012, FPL raised \$1.4 million through donations to the CTS program (Landey \& Rzad, 2014).

The state of Florida also offers plans to low-income families on a Federal level (Benefits in Florida, n.d.). Florida utilizes numerous plans as an aide to families in need. However, the term need is reserved for those whose household income is less than $150 \%$ of the poverty line and many do not include utilities as a benefit. The Florida Food Assistance Program was created for families without necessary funds to properly provide nutritious food and does not include utilities. The Florida Head Start program is an assistance program that allows children from birth to age five to participate in programs that strengthen their emotional development, cognitive development, social skills and education. These programs are seen in a variety of public elementary schools throughout the state. In order to be eligible for this program the family income for a family of three (a mother, father and child) must be equal to or less than $\$ 20,093.00$ (Eligibility requirements, 2015).

On a national level utility affordability programs are defined as the individual (or families) ability to pay for the utility service. These services are not designed for individuals who can pay for utility service, but are unwilling to do so. These services are designed for those who are deemed low-income (Fisher, Sheehan \& Colton, 2005). The majority of the affordability plans available in the state of Florida low-income is considered to be any household that earns less than $150 \%$ of the federal mandated poverty line.

Another issue with eligibility within affordability plans is the federal government forbids state and local governments from taking individuals assets into consideration when determining eligibility. This means that state and local governments are not allowed to review a person's tangible assets if they meet the income requirement. If an individual owns their home, their vehicle and is essentially debt free yet their income is equal to or less than $150 \%$ of federally mandated poverty line, they are able to receive assistance.

In order to establish a basic benchmark for the larger study, the following information was consolidated for establishing the ten utilities utilized in this study. Table 1 demonstrates the average utility bill compared to per capita income and the unemployment rate for the ten utilities. The data shows that there is significant need in the communities served by the utilities. The figure shows the average consumption uses by major household items. Water is a basic need and must be sustained for a healthy household. 
Table 1. Average utility bill.

\begin{tabular}{l|c|c|c}
\hline \multicolumn{1}{c|}{ Utility } & $\begin{array}{c}\text { Average Water } \\
\text { Utility Bill }\end{array}$ & $\begin{array}{c}\text { Per capita } \\
\text { Income (2009) }\end{array}$ & $\begin{array}{c}\text { Unemployment } \\
\text { Rate (2009) }\end{array}$ \\
\hline Okaloosa county Water \& Sewer & $\$ 71.91$ & $\$ 42288.00$ & $8.1 \%$ \\
\hline Gainesville Regional Utility & $\$ 63.56$ & $\$ 35573.00$ & $8.2 \%$ \\
\hline JAE (Jacksonville) & $\$ 64.97$ & $\$ 38937.00$ & $11.7 \%$ \\
\hline Lakeland City Water Utilities & $\$ 54.53$ & $\$ 32336.00$ & $12.5 \%$ \\
\hline Melbourne City Water & $\$ 86.73$ & $\$ 37454.00$ & $11.5 \%$ \\
\hline Miame-Dade Water \& Sewer & $\$ 40.45$ & $\$ 36357.00$ & $12.4 \%$ \\
\hline Orange County Water \& Sewer & $\$ 51.85$ & $\$ 36700.00$ & $11.4 \%$ \\
\hline Broward County Water \& Sewer & $\$ 70.41$ & $\$ 41185.00$ & $10.1 \%$ \\
\hline St. Petersburg Water & $\$ 69.62$ & $\$ 42885.00$ & $11.7 \%$ \\
\hline City of Cocoa & $\$ 67.35$ & $\$ 37454.00$ & $11.5 \%$ \\
\hline Sour
\end{tabular}

Source: AWWA 2012 Utility Rate Survey

Source: http://www.eflorida.com/profiles/CountyReport.asp?CountyID=27\&Display=al

Figure 2 demonstrates the breakdown for an average home water utility bill. It is important to note that wastewater charges are based from water usage. Water is a commodity that is necessary for survival as noted in figure 2. However, as table 1 demonstrates, it is not a cheap commodity. To compound the issue, those who cannot afford the service trend toward those who have bigger families, thus higher consumption and higher bills. Compounding the issue even further is that wastewater is measured by the amount of water used. Due to the higher costs to process wastewater, the added cost to the bill could be three to four times the amount of the cost of water used.

Figure 2. Percentages of water usage.

\begin{tabular}{l|c}
\hline \multicolumn{2}{l}{ Withour counting lawn watering, typical percentages of water use for a family of four are: } \\
\hline- Toilet flushing & $40 \%$ \\
\hline- Bath and shower & $32 \%$ \\
\hline- Laundry & $14 \%$ \\
\hline- Diswasing & $6 \%$ \\
\hline- Cooking and drinking & $5 \%$ \\
\hline- Bathroom sink & $3 \%$ \\
\hline
\end{tabular}

Source: http://www.co.okaloosa.fl.us/dept_ws_conserve.html

The following provides information on existing affordability programs at the ten utilities studied. As Table 2 indicates, there are very few formal affordability programs utilized by the ten utilities. Regulations governing utilities, each must be self-sustained and pay expenses from revenues. This means the revenues and fees collected must pay for operations, debt, capital improvement, and support. Utilizing funding for utilities from the general fund would be unfair to those tax payers who do not use the services. This paper explains the basics of a utility rate model. Future studies by this research group will analyze rate models used by the ten utilities to determine if there are funding sources for affordability. 
Table 2. Overview of affordability programs in ten Florida utilities.

\begin{tabular}{|c|c|c|}
\hline $\begin{array}{c}\text { Ten Florida } \\
\text { Municipality Utilities }\end{array}$ & Affordability Program & Sources of Funding \\
\hline $\begin{array}{l}\text { Okaloosa County Water } \\
\& \text { Sewer }\end{array}$ & $\begin{array}{l}\text { No official low income program that assist } \\
\text { customers. Municipality has an assistance } \\
\text { program that help customer with their utility } \\
\text { bills. This program is funded by third party } \\
\text { agents, state law mandate, and criteria for } \\
\text { funding set by the agencies. }\end{array}$ & $\begin{array}{l}\text { Local charities, churches, state and federal } \\
\text { agencies. }\end{array}$ \\
\hline Gainesville Regional Utilities & $\begin{array}{l}\text { No official low income program that assist } \\
\text { customers. Municipality has an assistance } \\
\text { program that help customer with their utility } \\
\text { bills. This program is funded by third party } \\
\text { agents, state law mandate, and criteria for } \\
\text { funding set by the agencies. }\end{array}$ & $\begin{array}{l}\text { Local charities, churches, state and federal } \\
\text { agencies. }\end{array}$ \\
\hline (JEA) Jacksonville & $\begin{array}{l}\text { No official low income program that assist } \\
\text { customers. Municipality has an assistance } \\
\text { program that help customer with their utility } \\
\text { bills. This program is funded by third party } \\
\text { agents, state law mandate, and criteria for } \\
\text { funding set by the agencies. }\end{array}$ & $\begin{array}{l}\text { Neighbor to Neighbor program managed by } \\
\text { United Way, and Catholic Charities. Local } \\
\text { charities, churches, state and federal } \\
\text { agencies. }\end{array}$ \\
\hline $\begin{array}{l}\text { Lakeland City } \\
\text { Water Utility }\end{array}$ & $\begin{array}{l}\text { No official low income program that assist } \\
\text { customers. Municipality has an assistance } \\
\text { program that help customer with their utility } \\
\text { bills. This program is funded by third party } \\
\text { agents, state law mandate, and criteria for } \\
\text { funding set by the agencies. }\end{array}$ & $\begin{array}{l}\text { Local charities, churches, state and federal } \\
\text { agencies. }\end{array}$ \\
\hline Melbourne City Water & $\begin{array}{l}\text { No official low income program that assist } \\
\text { customers. Municipality has an assistance } \\
\text { program that help customer with their utility } \\
\text { bills. This program is funded by third party } \\
\text { agents, state law mandate, and criteria for } \\
\text { funding set by the agencies. }\end{array}$ & $\begin{array}{l}\text { Local charities, churches, state and federal } \\
\text { agencies. Brevard County Community } \\
\text { Action program. Catholic Charities and the } \\
\text { Brevard County Salvation Army. South } \\
\text { Brevard Sharing Center, Project Response, } \\
\text { St. Vincent de Paul, Brevard County Children } \\
\text { \& Family Services, NVA Inc., Asscention } \\
\text { Catholic Church, \& Community Action } \\
\text { Team. }\end{array}$ \\
\hline $\begin{array}{l}\text { Miami-Dade Water } \\
\text { \& Sewer }\end{array}$ & $\begin{array}{l}\text { No official low income program that assist } \\
\text { customers. Municipality has an assistance } \\
\text { program that help customer with their utility } \\
\text { bills. This program is funded by third party } \\
\text { agents, state law mandate, and criteria for } \\
\text { funding set by the agencies. }\end{array}$ & $\begin{array}{l}\text { Low-Income Home Energy Assistance } \\
\text { Program (LIHEAP). Local charities, } \\
\text { churches, state and federal agencies. }\end{array}$ \\
\hline Orange County Utilities & $\begin{array}{l}\text { No official low income program that assist } \\
\text { customers. Municipality has an assistance } \\
\text { program that help customer with their utility } \\
\text { bills. This program is funded by third party } \\
\text { agents, state law mandate, and criteria for } \\
\text { funding set by the agencies. }\end{array}$ & $\begin{array}{l}\text { Local charities, churches, state and federal } \\
\text { agencies. }\end{array}$ \\
\hline $\begin{array}{l}\text { Broward County Water } \\
\& \text { Sewer }\end{array}$ & $\begin{array}{l}\text { No official low income program that assist } \\
\text { customers. Municipality has an assistance } \\
\text { program that help customer with their utility } \\
\text { bills. This program is funded by third party } \\
\text { agents, state law mandate, and criteria for } \\
\text { funding set by the agencies. }\end{array}$ & $\begin{array}{l}\text { Low-Income Home Energy Assistance } \\
\text { Program (LIHEAP). Local charities, } \\
\text { churches, state and federal agencies. }\end{array}$ \\
\hline
\end{tabular}

(Table 2 continued on next page) 
(Table 2 continued)

\begin{tabular}{l|l|l}
\hline \multicolumn{1}{c|}{$\begin{array}{c}\text { Ten Florida } \\
\text { Municipality Utilities }\end{array}$} & \multicolumn{1}{|c}{ Affordability Program } & \multicolumn{1}{c}{ Sources of Funding } \\
\hline St. Petersburg Water & $\begin{array}{l}\text { No official low income program that assist } \\
\text { customers. Municipality has an assistance } \\
\text { program that help customer with their utility } \\
\text { bills. This program is funded by third party } \\
\text { agents, state law mandate, and criteria for } \\
\text { funding set by the agencies. }\end{array}$ & $\begin{array}{l}\text { The } \\
\text { Empowerment through Utility Payments } \\
\text { Assistance Program, and The Utility } \\
\text { churches, state and federal agencies. Pinellas } \\
\text { Opportunity Council, We Help \& Free Clinic, }\end{array}$ \\
& $\begin{array}{l}\text { Day Star, St. Vincent De Paul, \& Pinellas } \\
\text { County Social Services. }\end{array}$ \\
\hline City of Cocoa & $\begin{array}{l}\text { No official low income program that assist } \\
\text { program that help customer with their utility } \\
\text { bills. This program is funded by third party } \\
\text { agents, state law mandate, and criteria for } \\
\text { funding set by the agencies. }\end{array}$ & $\begin{array}{l}\text { Local charities, churches, state and federal } \\
\text { agencies. Brevard County Community } \\
\text { Action program. Catholic Charities and the } \\
\text { Brevard County Salvation Army. South } \\
\text { Brevard Sharing Center, Project Response, } \\
\text { St. Vincent de Paul, Brevard County Children } \\
\text { \& Family Services, NVA Inc., Asscention }\end{array}$ \\
& $\begin{array}{l}\text { Catholic Church, \& Community Action } \\
\text { Team. }\end{array}$ \\
\hline
\end{tabular}

Source: Created by authors.

As Table 2 indicates, there are very few formal affordability programs utilized by the ten utilities. Regulations governing utilities dictate that each must be self-sustained and pay expenses from revenues. This means the revenues and fees collected must pay for operations, debt, capital improvement, and support. Utilizing funding for utilities from the general fund would be unfair to those tax payers who do not use the services.

As noted in table 2, most utilities do not have an official hardship/affordability program. However, in each case we found that utilities worked extensively to share charities, churches, and public service organizations that could help fund those in need. In some cases, the utility would extend payment options if the customer could not pay, but research showed that debt forgiveness is not an option.

Some utilities are working with other agencies to provide assistance to those in need. The City of St Petersburg Water dos not offer a low income program to its users but it does offer the following programs to its customers: The Local Interventions for Financial Empowerment through Utility Payments (LIFT-UP) program, and The Utility Assistance Program. The LIFT-UP program is a two year pilot program launched by National League of Cities (NLC) to help low income families pay their utilities bills and achieve financial stability. (NLC, 2013) The Utility Assistance Program is a utility fund established by the City of St Petersburg's to assist families experiencing difficulty with paying their utility bills.

In collaboration with NLC, the City of St. Petersburg is one of five cities taking part in a pilot program that seeks to help low-income families pay their utilities. The LIFT-UP model allows those in debt to city-owned utilities to restructure their obligation. The Miami-Dade utility system is examining alternative rate structures to address affordability and market rate housing. The goal is to add predictability to rent stabilization programs. Currently, the cost of utilities is not considered in the rent stabilization program. The municipality used a stakeholder survey to determine affordability requirements.

As noted in table 2, there are numerous agencies attempting to help those who cannot afford water and wastewater utilities. This research indicates that there is more to accomplish and a rate model that would allow municipalities to consider those in need would benefit the industry. The current research will be extended in an attempt to develop an affordability rate model. 


\section{CONCLUSION}

This paper is the introductory paper to a larger study that will be conducted during 2015 and 2016. Researchers on this study will conduct an analysis of the ten utilities to determine differences in funding and operational allocations compared with outflow, facilities, operations, and future projects.

The reality of today's economy and projections of future utility issues speak volumes to the need for a nationwide affordability program. This research is designed to determine available aid and create a model that can be considered by utilities when facing the issue of non-payment due to affordability. Due to the raising costs associated with water production and scarcity of the commodity, this issue is not going to improve in the near future. This group of researchers will continue to explore options available to utilities.

As noted earlier, utility rate models are regulated to ensure the water, wastewater, or irrigation system is self-sufficient. Models do not typically allow for funds to pay for those who cannot afford the utility. Continuation of this research to determine feasibility of an inclusion methodology to ensure that municipalities can provide help to those less fortunate is imperative.

\section{AUTHOR BIOGRAPHIES}

The seven authors of this research are members of the MBA program at Hodges University in Naples Florida. The research was conducted as part of an ongoing project to develop a rate model to help those who are in need. Hodges University is a liberal arts university serving the global community and southwest Florida.

\section{REFERENCES}

American Water Works Association, Raftelis Financial Consultants (2010), Water and Wastewater Rate Survey (Computer Software). Denver Colorado.

Anderson, T.A., \& Forrer, D. A., (2001). A comparative analysis of utility rate forecasting: The Cape Coral experience. Proceedings from the Production and Operations Management Society Conference, Orlando, Florida.

Bauman, D. D., Boland, J.J., \& Hanemann, W.M., (1998) Urban water demand management and planning. New York: McGrawHill, Inc.

Benefits in Florida. (n.d.). Retrieved from http://www.benefits.gov/benefits/browse-by-state/state/FL

CDM Memorandum to Cape Coral Utility Department, (May22, 1995), Cape Coral Rate Study, CDM Project/DCN: 6704-120RT-REP.

Eligibility requirements. (2015). Retrieved from https://www.leegov.com/dhs/Documents/FSS/EligibilityRequirements.pdf

Finance Director, (March 23, 2009, "Water \& Wastewater Rate Update Analysis - Supplemental to Rate Study Update", City of cape Coral Financial Services Department.

Fisher, Sheehan, \& Colton. (2005, March 1). Defining "affordable" water rates for low income affordability programs. FSC's $A w$ \& Economic Insights, p. 5. Retrieved from http://www.fsconline.com/downloads/FSC Newsletter/news2005/n2005_0304.pdf

Florida Weatherization Assistance Program. (n.d.). Retrieved June 17, 2015, from http://www.benefits.gov/benefits/benefitdetails/1847

Hartman \& Associates, Inc. (1995). "City of Cape Coral: Water and wastewater annual report fiscal year 1995", Hai Project No. 96-347.00, Fort Myers, FL: Author, (1995).

Infrastructure and growth leadership pillars. (2011, November 29). Retrieved from http://www.floridajobs.org/Business/statewide_forum/05-Strategy Statements2_Innovation Economic Development.pdf

Judge, G. R., Hill, C., Griffith W., Lutkepol, H., \& Lee, T. (1982). Introduction to the theory and practice of econometrics. New York N.Y.: John Wiley and Sons.

Killingsworth, W. (2013, August 16). Economic development: Taking care of business. Retrieved from http://flcmobile.com/wpcontent/uploads/2013/08/8-16-13-Economic-Development-Takin-Care-of-Business-Killingsworth.pdf

Landey, A., \& Rzad, Y. (2014, April 1). Approaches to Low-Income Energy Assistance Funding in Selected States. Retrieved from http://aspe.hhs.gov/hsp/14/LIHEAP/rb_LIHEAP.cfm

Lee County assistance programs. (n.d.). Retrieved June 13, 2015, from http://www.needhelppayingbills.com/html/lee_county_assistance_programs.html

Lee County Local housing assistance program. (2014).Prepared for participation in the state housing initiatives partnership program. Lee County Department of Community Development :Lee County Planning Division. Retrieved from: https://www.leegov.com/dcd/Documents/Planning/ah/LHAP.pdf 
LIHEAP. (n.d.). Retrieved June 17, 2015, from http://www.liheapch.acf.hhs.gov/profiles/Florida.htm\#state

Low income home energy assistance program. (n.d.). Retrieved from https://www.bocc.citrus.fl.us/commserv/housing/liheap.htm?

Nieswiadomy, M.L., \& Molina, D.J., (Aug., 1991). A note on price perception in water demand models. Land Economics 67, 3 , p. 352.

Nordin, John A., (Autumn 1976). A proposed modification to Taylor's demand analysis comment. The Bell Journal of Economics. p. $719-721$.

Raftelis Environmental Consulting Group, Inc., "City of Cape Coral: Performance audit of utilities division", Charlotte, NC: Author, (1995).

Robinson, J., \& Brown, R. (2011). The role of leadership behaviors and structures in community development. In Introduction to community development: Theory, practice, and service-learning. Los Angeles: SAGE.

Saunders, M. (1998). Water affordability programs. Denver, Colo.: AWWA Research Foundation and American Water Works Association.

Shinn, J., (Nov.,1985). Perception of price when information is costly: Evidence from residential electricity demand. Review of Economics and Statistics 67, pp. $591-598$.

Statement of agency organization and operation. (2014). Retrieved from http://www.floridajobs.org/about-us/who-we-are-andwhat-we-do/executive-staff-and-organizational-structure/statement-of-agency-organization-and-operation 
NOTES 